\title{
Fiber to the Home Unbundling and Retail Competition: Developments in the Netherlands
}

\author{
Annemijn van GORP \& Catherine MIDDLETON \\ Ryerson University, Toronto, Canada
}

\begin{abstract}
This study provides preliminary insights into how fiber to the home (FTTH) networks affect competition in the broadband Internet access market, and how, and if, competition on FTTH networks can be sustained. This study focuses on the Netherlands, a fast growing FTTH market with regulation mandating unbundling. Even though it is too early to paint a full picture of developments in the competitive landscape, initial findings suggest that rollout of FTTH has positive short-term effects on facilities-based competition. However, the extent to which competition on FTTH networks will develop at both the active operator and retail level remains unclear at this point. Additional uncertainties regarding the future of facilities-based competition suggest continued close monitoring of the market is necessary. Future research should address the extent to which competition at the active and retail level affect innovation.
\end{abstract}

Keywords: FTTH, broadband, Netherlands, open access, regulation, competition

B

roadband networks are increasingly described as essential infrastructure. For residential access, fiber to the home (FTTH) service is considered by many as the last mile technology of the future 1; it has even been called 'the final broadband service' (IDA \& SAKAHIRA, 2008). Due to the constraints of high upfront investment costs in FTTH networks, worldwide stakeholders are experimenting with business models while policy makers are contemplating measures to stimulate FTTH rollout. In particular, there is a growing call by policy makers, academics and consumer groups alike to build open access networks to enable service-based competition by allowing third party providers access to networks on a non-discriminatory and transparent basis to deliver content and services.

This study focuses on the Netherlands, where the FTTH market is growing quickly and regulation is in place to stimulate open access by mandating unbundling. The paper provides insights into (1) how FTTH

\footnotetext{
1 Reasons include very high transmission rates, low latency and separated layers enabling 'dedicated connections'.
} 
rollout influences competition in the broadband market, and (2) to what extent open access, and unbundling of FTTH in particular, is viable. Data have been collected through interviews with stakeholders in the sector and through analysis of secondary data.

The paper starts with a discussion of factors influencing investment and the role of regulation in stimulating competition. It then discusses FTTH developments in the Netherlands and the role of regulation in the Dutch market, followed by a discussion of business models to provide FTTH services. The impact of FTTH networks on broadband network development in general is considered, followed by discussion and conclusions.

\section{- Investment and competition in broadband markets}

Regulatory authorities have a number of options to try to stimulate investment in FTTH networks. First, a regulatory authority may explicitly opt not to regulate. For example, in the U.S. a deliberate choice has been made to not require open access. Indeed, some believe that the rollout of fiber networks by AT\&T and Verizon in the U.S. has been driven largely by regulatory forbearance, although at the same time it is also viewed as a response to significant competition from cable providers (CHOW, 2007). Another option is to require open access, either through mandating unbundling or resale/bitstream access, which often involves price regulation. Nationwide FTTH networks under construction in Singapore and Australia are designed for open access, and regulation in Japan, South Korea and Sweden (the OECD leaders in fiber broadband connectivity), requires open access to fiber networks (CHOW, 2007; OECD, 2010b; The Berkman Center for Internet \& Society, 2010). Many European countries are currently following trends of open access. The third option for a regulatory authority to remain silent and thus neither regulate nor explicitly decide not to regulate - is not desirable, as it presents significant uncertainties to potential investors about future developments and therefore may limit investment by private parties.

Given the widespread agreement that the high sunk costs of FTTH networks lead to significant economies of scale at the physical network layer (SADOWSKI, DE ROOIJ \& SMITS, 2006), open access policies seem particularly appropriate as a means of encouraging service-based competition among providers without requiring duplication of fiber facilities. 
However, incumbents tend to resist regulation, arguing that there is limited competitive advantage in investing in infrastructure they must make available to their competitors. Without open access obligations, fiber networks have the potential to lead to monopolistic ownership and services provision, and given their potential 'technological superiority' (i.e. capacity to deliver highest speeds) may eliminate facilities-based competition on other platforms (JANSSEN \& MENDYS-KAMPHORST, 2008).

To ensure that access seekers are treated equally by incumbent network owners, some countries have introduced operational or structural separation regimes ${ }^{2}$. Such regimes require incumbents to separate their wholesale operations from their retail operations, so that incumbents are unable to discriminate by providing more favorable access conditions to their own retail operations than to access seekers. In 2006, UK incumbent BT established Openreach to manage the local access network in that country, providing "equal, open and economic access to the UK network" for all communications providers (BT Group, 2009, p. 92). This action has been successful in increasing competitive broadband offerings in the UK using the existing copper network, resulting in higher speed, lower cost services for consumers (Ofcom, 2007). In 2009, Openreach announced that it would offer next generation network access (based on a mixture of FTTH and FTTC infrastructures) to $40 \%$ of homes and businesses in the UK by 2012 (OPENREACH, 2009), demonstrating that an operationally separated incumbent can make a business case for investment in fiber networks.

Even without imposed separation, an increasing number of studies find that sharing fiber infrastructure (i.e. providing wholesale services) can actually reduce costs and increase revenues for incumbents, thereby enabling incumbents to reach profitability at a lower level of retail market share (ELIXMANN, ILIC, NEUMANN \& PLUECKEBAUM, 2008; FELTEN \& SWAIN, 2009; The Berkman Center for Internet \& Society, 2010). While the specifics of cost reduction depend on context, and will vary across countries, there are three primary benefits to incumbents who share their fiber networks. First, FTTH operators gain wholesale revenues from the third party providers using their networks to serve additional retail customers. Second, incumbents share marketing efforts with third party providers using their wholesale services, which may increase the market share of FTTH over other infrastructures. Finally, wholesale constructions provide opportunity for the incumbent to focus more on operations rather than on service provision.

\footnotetext{
2 See CAVE (2006) for a discussion of operational separation in the EU.
} 
Sharing of fiber infrastructure can occur at different levels. FTTH provision can be characterized according to a three layered model (as shown in Figure 1), which includes the passive infrastructure layer, the active infrastructure layer, and the retail or services layer (BOURAS, GKAMAS, et al., 2009). The passive infrastructure layer consists of dark fibre, which may be leased to a (wholesale) active operator that lights the fiber and operates the active infrastructure. The services layer includes all services that can be offered over the network, which at present typically includes Internet access, television, and telephony (triple play) ${ }^{3}$.

In some networks more than one layer is managed by a single provider/company (COMPTER \& SCHEPERS, 2008), but in other cases separation policies restrict companies from operating at more than one level (in order to ensure that companies operating in wholesale and retail markets do not use their market power to impose unfavorable conditions on their retail competitors). For instance, in the next generation network under construction in Singapore the passive infrastructure is being built by OpenNet ${ }^{4}$ and the active infrastructure provider is Nucleus Connect ${ }^{5}$. Retail service providers will contract with Nucleus Connect on a non-discriminatory basis, as Nucleus Connect does not act as a retail service provider (Infocomm Development Authority of Singapore, 2009). In Australia, the National Broadband Network will offer wholesale bitstream access to retail service providers. The network will be built by NBNCo, which acts as the passive and active operator, but does not compete at the retail layer (NBNCo Limited, 2010).

In instances where separation provisions are not in place, services to consumers can be provided through partnerships between different providers operating in different layers, or in a sole-supplier environment. In the sole-supplier environment one provider is responsible for both infrastructure and service provision. In a wholesale-retail split, one party provides the infrastructure, and provides this on a wholesale basis to service providers that may, or may not take on an operator role by providing active infrastructure.

\footnotetext{
3 The OECD Directorate for Science Technology and Industry (2009) argues that cost savings generated by delivering health, transportation, energy and education services using FTTH networks would justify the cost of building national networks. To date however, there are few instances of government or social services being delivered over next generation networks.

4 http://www.opennet.com.sg/home/

5 http://www.nucleusconnect.com/
} 
However, even though an increasing amount of research points to the benefits of open access, it has also been found that a vertically-integrated model may be more appropriate for small-scale networks (SADOWSKI \& NUCCIARELLI, 2008), and that without government subsidies, small scale FTTH networks are unable to create service-based competition (SADOWSKI et al., 2006). Thus, a question remains as to what extent the size of FTTH networks influences the viability of service-based competition in the upper layers of the network (SADOWSKI et al., 2006). We explore this question more broadly below, by considering the development of FTTH networks in the Netherlands and the extent to which competition at the active and service layers is achieved.

Figure 1 - FTTH provision at different levels

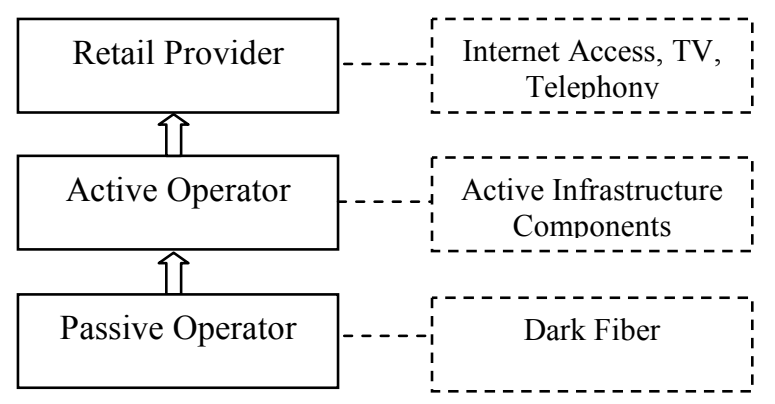

\section{FTTH developments in the Netherlands}

The Netherlands is a frontrunner in broadband uptake, ranked $1^{\text {st }}$ in the OECD with 38.1 broadband subscriptions per 100 inhabitants (OECD, 2010a). Although the Netherlands currently ranks lower with regard to FTTH deployment $\left(11^{\text {th }}\right)$, it has recently made significant strides forward and the number of connections is expected to grow significantly over the coming years (COMPTER \& SCHEPERS, 2008). In 2009, 3-4\% of broadband connections were with fiber (BUDDECOMM, 2009; OECD, 2010b). From March 2008-March 2009 the number of homes passed grew by $85 \%$ from 188,000 to 349,000 (STRATIX, 2009). $62 \%$ of these homes are ready for service (i.e. have fiber brought into the meter cupboard). The number of active subscribers in turn has grown from 84,000 to 139,000 from 2008-2009 (STRATIX, 2009). Stratix estimates that by the end of 2011 nearly one million homes will be passed. As of early 2009, 61 FTTH projects have been initiated (STRATIX, 2009). 


\section{The Role of regulation in fostering FTTH rollout and competition}

In the Netherlands FTTH deployment is encouraged by an extension of unbundling policies to include fiber, while at the same time relying on competitive market forces (LEMSTRA, 2009). Regulation is based on the principle of significant market power. At present it only applies to Reggefiber, which is the Netherlands' largest passive infrastructure provider, currently active in approximately $95 \%$ of FTTH networks (the other $5 \%$ are owned by various small entities). As of early 2009, Reggefiber had passed 336,000 homes with fiber networks, and 106,000 of these homes subscribe to FTTH (van ROOIJEN, 2009). By the end of the third quarter of 2009 the number of homes passed had grown to over $460,000^{6}$.

Reggefiber is a joint venture between investment firm Reggeborgh and incumbent telecom operator KPN. Reggeborgh has a background in real estate, and as such was familiar with projects with longer return on investment horizons than average telecom projects. Although Reggeborgh's core business was the provision of dark fiber networks, it has also ventured into active operation of these networks; currently under the name Reggefiber Wholesale. However, as a result of Reggeborgh's joint venture with KPN, it is intended that KPN will become the primary active operator for future Reggefiber projects. KPN made its first foray into FTTH in 2007 with a project in the city of Almere, working in cooperation with Reggeborgh - but not yet in joint venture (COMPTER \& SCHEPERS, 2008). Shortly thereafter, KPN became involved in an FTTH project in the city of Enschede as passive infrastructure provider, active operator and service provider. Since the end of 2009 , KPN has been wholesale provider on five city/neighborhood networks, and also acts as a service provider through its own retail brand.

In 2008 the Dutch competition authority NMA gave approval to the joint venture between KPN and Reggefiber. KPN has a $41 \%$ share in Reggefiber while Reggeborgh holds 59\%. The Dutch regulatory authority OPTA in December 2008 extended wholesale access obligations from copper (xDSL) to fiber (OPTA, 2008). After appeals that questioned this decision (STRATIX, 2009), in October 2008 this decision was repealed. In February 2010 a new draft decision was published that largely upholds the original decision regarding residential FTTH provision. It includes a requirement for open access to the local loop (i.e. unbundled local loop) by operators, price caps on unbundling rates, backhaul access, etc. to prevent discrimination and to

\footnotetext{
${ }^{6}$ See http://www.telecompaper.com/nl/article.aspx?cid=708722. Last accessed May 4, 2010.
} 
guarantee competition, but a separation regime has not been mandated. Price caps for wholesale remain the same as per the Tariff Decision Unbundled Fiber Access (FTTH) from June 2009 (OPTA, 2010). Reggefiber is required to offer active operators non-discriminatory wholesale access at $€ 14.50$ to $€ 17.50$ per month per line (BUDDECOMM, 2009), but currently provides access prices at about $€ 2.50$ below the price cap. OPTA will periodically evaluate Reggefiber's business case, and adjust the price cap if deemed necessary.

Wholesale broadband access (bitstream) in the Netherlands is currently not regulated in order to stimulate investment. By providing an open access requirement at the active infrastructure level, the threshold for entry is believed to be low enough to stimulate investment. Currently, KPN offers wholesale broadband access voluntarily, although it is unknown to what extent this is an attractive service to retail providers.

\section{Business models in the Netherlands}

A variety of investment and business models exist in the Netherlands, with both pure private investment and public-private partnerships. Although Reggefiber plays a key role in the Dutch FTTH market, FTTH projects have been initiated by others, including municipalities and end users in customerowned networks. Further, networks vary with regard to the (number of) active operators and service providers, which has implications for the level of competition and customer choice. In addition, the role of the active operator matters in light of competitive outcomes: for example, is the active operator a wholesale operator only or does it also compete in services provision? These aspects of various business models will be analyzed below with an eye towards how the structure stimulates competition and wide availability of (differentiated) services.

\section{Private network ownership}

As already indicated, Reggefiber is currently involved in about $95 \%$ of fiber projects in the Netherlands. Even though unbundling obligations are in place, currently few independent operators are actually active on Reggefiber's networks. The vast majority of networks are operated by Reggefiber Wholesale, with joint venture partner KPN active in only a few 
projects (formally in 5 cities). Independent active operators currently include Solcon (in Dronten) and BBned (in Amsterdam and Rotterdam). Online is expected to enter the FTTH market as active operator in 2010, and has announced it will enter the network of Almere, although it is not yet active. Similarly, Tele2 has announced plans to enter the FTTH market as active operator in $2010^{7}$. All independent active providers are also current DSL providers acting as CLECs.

Until very recently all FTTH networks were served by only one active operator. And, even though Reggefiber is required to provide wholesale access, many networks are characterized by vertical integration: Reggefiber in many instances acts as both passive and active operator, and also often as service provider. Although Reggefiber initially intended to solely act as passive operator, it experienced difficulties in finding other parties interested in assuming the role of active operator. Hence, before the joint venture with KPN, Reggefiber became an active operator as well (currently known as Reggefiber Wholesale), and also extended its focus to service provision through two service providers: XMS, initially through a partnership with BBNed (a subsidiary of Telecom Italia) but as of April 2010 solely owned by Reggefiber, and Edutel, which constitutes a partnership of Reggefiber with Fontys Hogeschool Eindhoven (an institution of higher education).

\section{The role of local government in FTTH networks}

Involvement of local government in fiber projects occurs through a variety of roles, ranging from investor in, or operator of the passive infrastructure (dark fiber), to active operator or as provider of access, services and content (LEHR et al., 2003; SADOWSKI, NUCIANELLI \& DE ROOIJ, 2009). The desirability of government operation of networks or service provision is often strongly contested: Municipalities may have fewer incentives than private providers to operate efficiently, which could potentially result in anticompetitive strategies (LEHR, SIRBU \& GILLETT, 2006). In the Netherlands to date the most common role for government, albeit on a relatively small scale, has been as a network owner: According to one stakeholder in the Dutch FTTH sector, municipal investment has occurred primarily in Amsterdam, Rotterdam and Eindhoven - three of the Netherlands' five largest cities. Amsterdam Citynet started out with the

\footnotetext{
7 See http://webwereld.nl/nieuws/63720/tele2-begint-met-fiber-to-the-home.html. Last accessed May 4, 2010.
} 
municipality aggregating passive infrastructure (SADOWSKI et al., 2009), but later contracted Reggefiber to take over the physical infrastructure management.

Although to date the local government's role in the Netherlands has been limited, there is continued debate on the desirability of government involvement. The role of local government should be viewed in light of the national government's broader role in stimulating next generation network rollout in the Netherlands. An expert panel convened in 2002 recognized that in geographical areas where private sector investment was less likely due to profitability concerns, public private partnerships could be "a powerful instrument" to stimulate further broadband development. Nevertheless, the panel stressed that competition had to be at the forefront of government policy and a driver of incentives to stimulate rollout (The Berkman Center for Internet \& Society, 2010, p. 294). Additionally, in 2004 the Ministry of Economic Affairs published an outline for a broadband strategy, which also emphasized the role of municipalities in network building, and noted the need for open access (unbundling of the infrastructure) and coordination of nationwide standards (The Berkman Center for Internet \& Society, 2010). A recent recommendation by the Task Force Next Generation Networks further emphasizes the potential role municipal and provincial government could play in facilitating or even (co-)financing next generation network rollout (although preferably less than $50 \%$ of the total investment) (TaskForce Next Generation Networks, 2010a; TaskForce Next Generation Networks, 2010b). State aid is prohibited, and the Market Economic Investor Principle applies to government investment, meaning that (according to the EC Treaty) government may invest on the same grounds as the private sector would.

The desired role for government nevertheless remains contested. Given the increasing attention to the particular suitability of fiber for next generation infrastructure, cable companies have expressed their concerns ${ }^{8}$. In addition, in December 2009 the telecom regulatory authority Opta and competition authority NMA indicated their preference for a limited role for government: due to concerns of unfair competition, they prefer a coordinating role for government by means of providing licenses, etc. ${ }^{9}$. This debate is likely to continue for a while to come, and even though to date investment by

8 See e.g. the weblog at the site for the association of cable companies: http://www.nlkabel.nl/nl; and the association's reaction to the recommendation of the TaskForce Next Generation Networks at: http://www.nlkabel.nl/nl/Home/Dossiers/NextGeneration-Networks/Task-Force-supersnel-breedband.aspx.

9 See e.g. http://www.telecompaper.com/nl/article.aspx?cid=709838. 
municipal and provincial government has been limited, the facilitator role of local government is key to successful FTTH rollout. For instance, Reggefiber indicates that a key criterion for network rollout is the municipality's willingness to facilitate rollout in terms of providing licenses, detouring traffic during times of digging, providing maps, making agreements about reconstruction of roads, etc. Of course, if a municipality is not willing to facilitate, rollout time and costs increase significantly.

\section{Customer-owned networks}

Customer-owned networks are distinct in that they are built with a view to offering more more choice for the end-user. When end-users own the network they will typically incur fewer costs over time, and will avoid the infrastructure 'lease' costs that are incurred when another party owns the network.

In September 2009, customer-owned network operator OONO made headlines in telecom news. OONO had become the active operator of a customer-owned network in 'The Red Apple' apartment building in Rotterdam, a network built as the result of apartment owners' initiative to have its own fiber network. Owners paid $€ 400$ to have their apartments connected ${ }^{10}$. The network has a very high uptake rate of approximately $90 \%$. The Association of Owners pushed the project and played a vital role by contracting various parties to design and implement the network. It contracted service providers and hired OONO to 'light' the network. In this case, there is no vertical integration as each involved party operates on only one of three levels of the fiber provision model. Because OONO's revenue from the Association of Owners is dependent on the number of active users, it has an incentive not to become a service provider. The more connections OONO has, the more revenue it will generate. OONO is better off with as many service providers as possible, and does not want to compete with service providers as this might cannibalize its income as active operator.

Currently three service providers are active on the network: one that provides telephony services, one that provides internet access, and one that

\footnotetext{
10 The price is lower than the average prices discussed by Reggefiber. According to OONO, this is the result of the use of a GPON network rather than a Point-to-Point network, as well as The Red Apple being an apartment building rather than a collection of town homes, thus eliminating the need for digging, etc.
} 
provides television services. The service providers are small providers; and are not well known in the country. Although today it is common for service providers to offer triple play services (voice, internet and video), at The Red Apple that has not happened because the three providers independently offer their services at the most attractive prices. The network can support many service providers, and efforts are ongoing to bring more providers on board.

OONO has been approached by multiple parties, including housing corporations, municipalities, and associations of companies, to investigate the possibility of developing user-owned networks elsewhere. This indicates that possibly in the future more initiatives for customer-owned networks will be taken. However, although customer-owned networks sound promising, there are some challenges. First, even though customers can theoretically make their own choices with regard to service providers, this is dependent on there being multiple providers offering services. To date at the Red Apple network, there is no competition among service providers. This may change in the future, particularly as OONO's footprint grows and service providers can target multiple networks at marginal extra costs. The customer-owned network model is of course very different from Reggefiber's business model as it does not encourage competition of different active operators. The active operator in this model has a fairly 'passive' role in that it is not involved with attracting service providers because the owners of the network take up this role.

Finally, the future of customer-owned networks might not be easy. As observed by Reggefiber, the complexities of maintaining dark fiber networks are often underestimated. Owner-operated networks may not offer professional technical support, relying instead on support from volunteers who may not be able to meet the service standards expected by their 'coowner' neighbors.

\section{The influence of business models on service-based competition and choice of service}

The three models discussed above have different implications in terms of how they stimulate service-based competition and increase customer choice. Structural separation could be argued to theoretically best stimulate service-based competition: A pure dark fiber provider will want to have as many active operators on top of its network as it will generate most revenue. 
Similarly, an active operator that is a wholesale provider only, will want as many service providers as possible as it will generate the most revenue. But even though Reggefiber claims it wants as many providers as possible, a joint venture like that between dark fiber provider Reggefiber and incumbent KPN, as well as Reggefiber's partnerships with two service providers, could of course lead to protective behavior (i.e. Reggefiber trying to prohibit other active operators and service providers from using their networks). Regulation largely prevents such behavior at the active operator level, but there is no regulation at the service provider level. Nevertheless, to date most networks have a few service providers. The question then is: Would entry by third parties, at either the active operator level or service provider level be better stimulated with government owned or customer-owned networks, as opposed to privately owned networks? Not necessarily. Customer-owned networks theoretically offer more choice as the 'customers' themselves choose service providers from those they have granted access to the networks. But it is more difficult for customer-owned networks to get organized to attract these third party providers; whether they are an association of owners of an apartment building or a municipality, telecom providers simply have more expertise in this area. On the municipal side, although government ownership would likely imply openness towards active operators, it is the active operators that are responsible for granting access to service providers so choice of service providers is dependent on active operators' efforts to bring a variety of service providers on board.

Additionally, even if open access is the goal, the issue of scale and first mover advantage will have a significant impact on the outcome. The issue of scale is related to take-up rates, and is key in determining profitability. Currently most FTTH networks in the Netherlands have about $20-40 \%$ take up rates. For a dark fiber provider to go ahead with a rollout, various mechanisms are used to estimate expected take up rates. In some instances 'demand bundling' has taken place where customers signed up prior to rollout. In particular, prior to KPN involvement, Reggeborgh's projects relied on this approach. Taking advantage of community FTTH champions, volunteer organizations try to 'market' FTTH to neighborhoods and have people sign-up prior to rollout. In areas where demand bundling takes place, once $40 \%$ coverage is reached, a decision is made to roll out the network. Reggefiber indicates that this approach has worked well, and sometimes has resulted in take up rates as high as $60 \%$. Another method is to estimate traffic statistics and then take a risk by opting for particular areas that would appear to be favourable. 
The take-up rates that are needed for sustainability are still unclear. COMPTER \& SCHEPERS (2008) suggest that the business cases for both passive and active infrastructure layers are based on a take-up rate of $50 \%$; i.e. $50 \%$ of connected homes should subscribe. However, stakeholders from the sector have different views, which vary from rough estimates of active operators being profitable at $10-15 \%$ uptake of a network, to a couple of tens of thousands of connections. Therefore, the extent to which small operators have a business case is unclear, as is thus the extent to which servicebased competition at the active operator level can be viable.

A study by SADOWSKI et al. (2009) reveals that the 'OnsNet' FTTH project in Nuenen reached a break-even point at a penetration rate of $31 \%$. Even though the project was subsidized, calculations indicate that without subsidy the break-even point would have been at 33\% (SADOWSKI et al., 2009). In this specific case, it was determined that a first competitive service provider would generate profits at $53-55 \%$ with a subsidy in place, whereas without subsidy a market structure with two service providers would emerge only at levels close to full penetration. SADOWSKI et al. (2009) therefore argue that if open access is not mandated at the retail level, there may be a threat that - as with the case of Ons Net - competitive service providers will not enter and service level competition will not emerge.

Active operators incur some investment costs (although their costs are significantly lower than those of dark fiber operators), but may also obtain economies of scale. The primary costs involved with active operation, as related to Reggefiber networks, are as follows: Lines have to be activated for each customer (at Reggefiber the connection per home costs $€ 150-200$ on an annual basis per line activated, with monthly access to the passive infrastructure costing from $€ 12.00-17.50)$. In addition comes a $€ 6000$ rent for an Area point of presence (PoP) where lines from individual homes are aggregated at the 'neighborhood' level, and $€ 7200$ rental costs on an annual basis for a connection between an Area PoP and City PoP (that aggregates connections with multiple Area PoPs). Finally, there are one time fees that include $€ 100$ to activate a home connection and a $€ 3000$ fee to activate an Area PoP (van ROOIJEN, 2009). Hence, the number of customers around one Area PoP will play an important role in determining profitability. Indeed, it is indicated that possibly the most significant economies of scale can be found in the PoP, to which 2500 customers can be connected. Once a PoP is implemented, the marginal costs of adding customers to reach full capacity are very low. Other economies of scale are not as significant. However, operators that are active in multiple networks require more 
equipment and can negotiate better prices based on the volume of purchases.

Beyond the question of the extent to which competition at the active operator level is possible, there is the question of how many service providers choose to offer services on a given network. The price of wholesale access will be an important determinant in service providers' market entry. Economies of scale for service providers, particularly those that have taken advantage of bitstream access for DSL, are more difficult to achieve than for active operators. Nevertheless, the service (IT) platforms developed by DSL providers (KPN, BBNed, Online) are also used for fiber, and thus do give some economies of scale.

Although theoretically regulation allows any active operator to begin offering service when a new network is established, the lack of competition in the market to date may lead to first-mover advantages. For instance, on a network with $60 \%$ uptake, the interest for new entrants might not be significant. Nevertheless, even though Reggefiber Wholesale to date has the most significant first-mover advantage, it is expected that KPN will start as active operator in many networks, in order to accommodate its copper customers. Of course, this assumes customers will choose to transition from copper to fiber networks. In addition, KPN's move might trigger reaction by others - the current DSL providers - BBNed, Online and Tele2 to enter the FTTH market.

\section{The future of alternative infrastructures}

The future of competition in the broadband market will be influenced by the competition that develops on top of FTTH networks. However, other infrastructures may still have a role to play in the market by driving service innovation and consumer choice. Although exactly what constitutes facilitiesbased competition, and how many infrastructures are needed to establish such competition is still a point of debate, many argue that facilities-based competition is well-established in the Netherlands (The Berkman Center for Internet \& Society, 2010; de BIJL \& PEITZ, 2008; LEMSTRA, 2009). Even though a number of operators are focusing on FTTH, there are other choices for customers who want access to 'next generation' networks, including cable and VDSL2. 
The Netherlands' largest cable providers UPC and Ziggo, that reach respectively 2.8 and 4 million out of 7 million homes, are upgrading their networks to DOCSIS 3.0 standards. Download speeds up to $120 \mathrm{Mbps}$ have already been achieved by UPC in Amsterdam (COMPTER \& SCHEPERS, 2008). Just a few smaller cable operators have decided to replace their cable network with fiber to the home (STRATIX, 2009), including CAIW.

The future of Fiber to the Curb (FTTC) in combination with VDSL2 is less straightforward however, particularly as incumbent KPN's rollout focus of FTTH vs. FTTC remains unknown. KPN has received regulatory approval to implement FTTC, linked to a phasing out of traditional DSL unbundling from central offices (LEMSTRA, 2009). In 2005 KPN announced that from 20062010 approximately 28,000 street cabinets would be connected to fiber and VDSL2, and in early $2007 \mathrm{KPN}$ announced that it would offer FTTC nationwide (COMPTER \& SCHEPERS, 2008). Formally, in the fall of 2009, KPN said it was still evaluating its pilots for FTTC/VDSL2. In addition, it is also evaluating its FTTH projects. In August 2009 it was reported that KPN was serving six neighborhoods in five cities with trial FTTC/VDSL2 services ${ }^{11}$.

While KPN has largely been focusing on installing street cabinets to enable VDSL2 service provision, in August 2009 competitor Tele2 announced that it would start providing FTTC with VDSL as of September 2009 in 40 cities and towns, with an expected growth to 2 million households by the end of 2011 (TelecomPaper, 2009). This service is capable of providing $60 \mathrm{Mbps}$ download and $6 \mathrm{Mbps}$ upload speeds, from the Central Office rather than from street cabinets. As a current DSL provider with active equipment, Tele2 only needs to replace DSLAMs, routers and the like with VDSL equipment, rather than also having to extend its fiber reach closer to the home and thus eliminating significant investments. But not all 7 million households in the Netherlands can be reached with this approach (TelecomPaper, 2009).

In October 2009, KPN announced that it would follow in the footsteps of Tele2, and also start offering VDSL services from Central Offices. Speeds for many homes would be limited to 30 or $40 \mathrm{Mbps}$ with this approach, but it enables quick coverage of $80 \%$ of homes in the Netherlands ${ }^{12}$. This quick

11 See "Tele2's VDSL rollout a no-brainer". News article August 28, 2009, downloaded from: http://www.telecompaper.com/news/article.aspx?cid=688321.

12 http://www.telecompaper.com/nl/article.aspx?cid=699557. 
upgrade, which is not very capital intensive, will enable KPN to roll out its interactive IPTV as well as new HDTV services on large scale as of Q2 201013.

Given that co-location for FTTC/VDSL from street cabinets is very difficult (due to mere physical space constraints, for instance), and because VDSL from the Central Office does not provide speeds over $60 \mathrm{Mbps}$, cable is likely to be the only alternative last mile infrastructure that offers competition to FTTH deployments in the future (although cable upload speeds do not match those of fiber networks). Indeed, KPN and Tele2's offerings of VDSL2 from Central Offices are said to be interim solutions leading up to future fiber service offerings ${ }^{14}$.

Although the future of FTTH is not yet clear cut, and various last mile technologies play their part in stimulating competition, the recent growth of FTTH can be argued to have played a significant role in stimulating this infrastructure competition. Indicative of the role of FTTH are the names for new cable and VDSL2 services: UPC offers high speed service by the name of "Fiber Power Broadband" service, whereas Tele2 offers its VDSL service under the name "Fiberspeed". Nationwide commercials are being aired by cable operators to attract new customers; specifically referring to the upgrading of their networks. For example, in the summer of 2009 Ziggo was advertising that upgraded speeds of $80 \mathrm{Mbps}$ would be available in Fall 2009, and speeds above $100 \mathrm{Mbps}$ available in 2010 15. Thus, to conclude, the development of broadband infrastructure in the Netherlands is fast moving due to heavy competition across infrastructures.

\section{Discussion and conclusions}

This study provides (preliminary) insights into how the rollout of FTTH influences competition in the Dutch broadband market and the extent to which service-based competition seems viable. Unlike FTTH projects in some other countries (e.g. Singapore, Australia), Dutch unbundling policies

\footnotetext{
13 See "KPN Consumer NL Q3: groei in tv en vast en mobiel breedband", 27 October 2009. Accessed October 28, 2009 at http://www.telecompaper.com/nl/article.aspx?cid=699010.

14 See http://www.telecompaper.com/nl/article.aspx?cid=699557.

15 The actual fastest speed offered as advertised on www.ziggo.nl in May 2010 is 50 Mbps however.
} 
allow for competition at the active infrastructure layer of the network. Competition at the retail level is encouraged, but not mandated, and to date most retail service providers are also active network operators.

The development of FTTH networks in the Netherlands has prompted a response from facilities-based competitors, who have increased their investment in existing cable and DSL broadband networks. Cable operators are upgrading their networks to DOCSIS 3.0 standards, allowing them (at least for the time being) to match the download speeds offered by FTTH providers, and marketing their services to customers as being similar to FTTH. In addition, VDSL is being offered from central offices. Although VDSL speeds do not match those offered by fiber or cable, they are much higher than existing DSL speeds, and may meet the short to medium term needs of many customers. It is not clear whether cable will remain competitive with fiber networks over time because it may not be able to match speeds in the longer run (particularly upload speeds). Nevertheless, by investing in these networks in the short term, existing providers can continue to earn revenues on their infrastructure investments and discourage their customers from switching to fiber while they develop strategies for staying competitive in the future (perhaps through future upgrades to the network or by migrating to fiber infrastructures themselves in the longer term).

As the future of facilities-based competition remains unsure, there is potential for fiber to become the sole broadband infrastructure. To avoid a potential move of the sector towards a monopoly therefore requires development of service-based competition on fiber networks. This study showed that to date service-based competition on FTTH networks in the Netherlands is limited. Except for the recent entry in early 2010 of OONO and Teleplaza as active operators on the Rotterdam fiber network along side the active operator BBNed ${ }^{16}$, currently all other networks in the Netherlands have one active operator. The extent of scale that is needed for both active operator and service provider competition is not yet clear, and thus it remains unknown how many active operators networks could actually support. Thus, even though the regulatory requirement for unbundling has led many to believe that traditional vertical integration of networks and service provisioning is now being challenged (LEMSTRA, 2009), the extent to which this will happen remains a question, one that cannot yet be answered.

16 See http://www.glasvezelrotterdam.nl/site/?p=nieuws\&id=27. Last accessed May 13, 2010. 
This also brings to bear the question of whether this is a good or bad thing: In various countries models for FTTH provisioning are based on structural separation of the networks, with competition happening at the services level only. While a significant share of innovation is likely to happen at the active operator level where the electronic components of the network are implemented, the added value of fiber networks over current broadband infrastructure is expected from the development of innovative services, in areas like health care, security and education. Providers of such services will have more control when they have direct access to the active infrastructure rather than providing their services via the internet. At present services delivered over FTTH network are primarily traditional triple play services (telephony, internet access and tv), and development of innovative new services will likely go hand in hand with this access to the active layer. This implies that open access at the service/retail level could be the key to future innovations. Future research should address the extent to which competition at the active and retail level affect innovation and choice of service for customers.

\section{References}

de BIJL, P. \& PEITZ, M. (2008): "Innovation, convergence and the role of regulation in the Netherlands and beyond", Telecommunications Policy, 32, 744-754.

BOURAS, C., GKAMAS, A., et al. (2009): "Broadband municipal optical networks in greece: A suitable business model", Telematics and Informatics, 26, 391-409.

BT Group (2009): "BT Group plc Annual Report \& Form 20-F 2009". http://www.btplc.com/Sharesandperformance/Annualreportandreview/pdf/BTGroupAn nualReport2009smart.pdf (accessed 5 May 2010).

BuddeComm. (2009): Netherlands - Fibre-to-theHome Developments, Paul Budde Communication Pty Ltd.

CAVE, M. (2006): "Six Degrees of Separation Operational Separation as a Remedy in European Telecommunications Regulation", CoMmUNICATIONS \& STRATEGIES, 64, 89-104.

CHOW, E. (2007): "Fibre-to-the-Home: Taking the plunge", Telecommunications Journal of Australia, 57(2-3), 35.31-35.33.

COMPTER, E. \& SCHEPERS, J. (2008): Fibre-to-the-Home (FttH) in the Netherlands, Report commissioned by OPTA: TelecomPaper.

ELIXMANN, D., ILIC, D., NEUMANN, K.-H. \& PLUECKEBAUM, T. (2008): The economics of next generation access - Final report, Bad Honnef, Wik Consult: Study for the European Competitive Telecommunication Association. 
FELTEN, B. \& SWAIN, W. (2009): Fiber to the Home: Making that business model work, Yankee Group Webinar 06/30/2009.

FTTH Industry Special Interest Group (2008): An Industry Vision for the National Broadband Network Plan.

http://www.budde.com.au/presentations/content/An\%20Industry $\% 20$ Vision $\% 20$ for $\% 2$ 0the\%20National\%20Broadband\%20Network\%20Plan\%20v1.1.pdf

(retrieved 12 March, 2008).

HOGENDOORN, C. (2007): "Broadband Internet: net neutrality versus open access", International Economics and Economic Policy, 4(2), 185-208.

IDA, T. \& SAKAHIRA, K. (2008): "Broadband migration and lock-in effects: Mixed logit model analysis of Japan's high-speed Internet access services", Telecommunications Policy, 32, 615-625.

Infocomm Development Authority of Singapore (2009): "Industry Structure for Effective Open Access". http://www.ida.gov.sg/Infrastructure/20090731125844.aspx (accessed 16 March 2010).

JANSSEN, M. C. W. \& MENDYS-KAMPHORST, E. (2008): "Triple play: How do we secure future benefits?", Telecommunications Policy, 32, 735-743.

LEHR, W., SIRBU, M. \& GILLETT, S.:

- (2003): "Broadband open access: Lessons from municipal network case studies", paper presented at the TPRC.

- (2006). "Wireless is changing the policy calculus for municipal broadband", Government Information Quarterly, 23, 435-453.

LEMSTRA, W. (2009): "Do we need policy 3.0 for telecom 3.0? The case of the Netherlands", paper presented at the TPRC.

NBNCo Limited (2010): NBN Co Response to Industry Submissions - Proposed Wholesale Fibre Bitstream Products, Sydney: NBNCo Limited.

http://www.nbnco.com.au/content/upload/files/Response to Industry Submissions/N BN Co response to consultation submissions.pdf (accessed 5 May 2010).

OECD:

- (2010a): OECD Broadband Subscribers Per 100 Inhabitants, by Technology, June 2009. http://www.oecd.org/dataoecd/21/35/39574709.xls (accessed 15 March 2010).

- (2010b): Percentage of Fibre Connections in Total Broadband among Countries Reporting Fibre Subscribers, June 2009.

http://www.oecd.org/dataoecd/21/35/39574709.xls (accessed 15 March 2010).

OECD Directorate for Science Technology and Industry (2009): Network Developments in Support of Innovation and User Needs, Paris: OECD Working Party on Communication Infrastructures and Services Policy.

http://www.olis.oecd.org/olis/2009doc.nsf/LinkTo/NT0000889E/\$FILE/JT03275973.P DF (accessed 5 May 2010). 
Ofcom (2007): "Impact of the Telecoms Strategic Review - Evaluation Statement". http://www.ofcom.org.uk/telecoms/btundertakings/impact1006/impact1006.pdf (accessed 5 May 2010).

Openreach (2009): Super-fast Fibre Access - The future starts here. http://www.openreach.co.uk/orpg/products/nga/downloads/Super fast fibre access. pdf (accessed 5 May 2010).

\section{OPTA}

- (2008): Marktanalyse: Ontbundelde toegang op wholesale niveau - Besluit, Den Haag: OPTA/AM/2008/202719.

- (2010). Marktanalyse breedband: Ontbundelde toegang op wholesale-niveau. Ontwerpbes/uit, Den Haag, 1 February 2010. OPTA/AM/2010/200209.

SADOWSKI, B., de ROOIJ, M. \& SMITS, J. (2006): "State aid, open access and market size: Two cases of FTTH network implementation in Dutch municipalities", Paper presented at the the $17^{\text {th }}$ European Regional ITS Conference.

SADOWSKI, B., \& NUCCIARELLI, A. (2008). "New challenges in municipal broadband network management: From vertical integration to wholesale-retail model", paper presented at the bi-annual ITS conference.

SADOWSKI, B., NUCIANELLI, A. \& de ROOIJ, M. (2009): "Providing incentives for private investment in municipal broadband networks: Evidence from the Netherlands", Telecommunications Policy, 33 (10-11), 582-595.

Stratix (2009): Netherlands FTTH, $1^{\text {st }}$ Q. 2009, Hilversum: Stratix.

TaskForce Next Generation Networks:

- (2010a): Supersnel Breedband voor al Uw Bewoners en Bedrijven: Menukaart. http://www.rijksoverheid.nl/documenten-en-publicaties/kamerstukken/2010/03/23/taskforce-ngnen-twee-rapporten-over-supersnel-breedband.html (March 16 2010).

- (2010b): Breed aan het Net, Gemeenten aan Zet. Letter to the Minister of Economic Affairs, March 152010.

http://www.rijksoverheid.nl/documenten-en-publicaties/kamerstukken/2010/03/23/taskforce-ngnen-twee-rapporten-over-supersnel-breedband.html

The Berkman Center for Internet \& Society. (2010): Next Generation Connectivity: A review of broadband Internet transitions and policy from around the world. Final report, February 2010: The Berkman Center for Internet \& Society at Harvard University.

http://cyber.law.harvard.edu/sites/cyber.law.harvard.edu/files/Berkman Center Broa dband Final Report 15Feb2010.pdf.

van ROOIJEN, J. (2009): "Reggefiber Group BV: Investing in Fiber-to-the-Home in the Netherlands", Presentation at the ECTA Fibre Conference, Brussels, 25 June 2009. http://www.apritel.org/fotos/editor2/Jan van Rooijen.pdf. 